DE DE GRUYTER

OPEN

DOI 10.1515/pesd-2015-0004

PESD, VOL. 9, no. 1, 2015

\title{
ASSESSING THE LOCAL ENVIRONMENTAL PERFORMANCE IN WESTERN MOLDAVIA (ROMANIA)
}

\begin{abstract}
Alexandra Sandu ${ }^{1}$, Alexandru Bănică ${ }^{2}$
Key words: environmental performance, indicators, local level, cluster analysis

Abstract. The environmental performance is a result of measurable characteristics emerging from the functionality of integrated environmental management systems based on various sustainable development policies at different administrative levels. This paper aims to quantify some dimensions of environmental performance in terms of outcomes and administrative efficiency for Western Moldavia region, using the latest available data. The obtained results demonstrate the territorial heterogeneity of environmental state, pressure and spatial resilience by highlighting the importance of ecosystems viability (forest cover, land degradation), sustainable local governance (environmental expenditure), energy, water quality, sanitation and environmental health (sanitation services, access to water and sewage, use of renewable energy). If completed in future by integrating other local environmental performance indicators the outcome of this research could become a viable tool for local and regional system of government in establishing policies in order to effectively preserve the environment.
\end{abstract}

\section{Introduction}

The environmental performance is an important component for understanding the capacity of a system to cope with the anthropogenic stress, a good approach in dealing with the environmental issues showing a high resilience capacity. Meanwhile it is important to describe environmental performance at all scales of governance and to envisage indicators that are measurable and comparable over time and across units of analysis. The environmental indicators are numerical

\footnotetext{
${ }^{1}$ Msc. Stud. ,"Ecole Normale Supérieure de Lyon", France "Alexandru Ioan Cuza" University of Iași, alexandra_sandu_fr@yahoo.fr

${ }^{2}$ Lecturer PhD, "Alexandru IoanCuza" University of Iaşi.
} 
values that can derive from actual measurements of pressure, state, condition and exposure of the ecological systems or human health over a specified geographic area (EPA, 2003). Fulfilling this conditions, but comprising uncertainty in a higher degree (Perotto et al., 2008), the indicators of environmental performance can be applied from global to national, a form regional to individual companies' level. The difficulty comes from the fact that there are no comparable sets of national environmental indicators and no common standards. The most comprehensive methodology and indicators in this area is the Environmental Performance Index (EPI) created in collaboration by Yale and Columbia Universities (Esty et al. 2005,Esty et al. 2006, Esty et al. 2008). The purpose of EPI is to rank countries taking into account two high priority environmental policy areas: protection of human health from environmental harm and protection of ecosystems. There are 20 indicators aggregated in these two areas, EPI measuring how close countries are to meeting internationally established targets or how they compare relative to the best performing countries (EPI Report, 2014).

In Romania, the assessment of environmental performance at national level was targeted by many researches (Sova et al, 2014; United Nations Reports, 2001, 2012; Tabără et al., 2013), but at a more detailed - regional or county - level, there are few attempts (Mocanu-Perdichi, 2009; Bran et al., 2011; Breabăn et al, 2013;Bănică et al, 2013) and even fewer were done at a communal scale or by multi-scale analyses (Surd, 2011). Therefore, this study tries to assess the environmental performance at a local level, taking into account indexes related to key fields such as sanitation services, forestry cover, land degradation, expenditures for environment and utilities modernization. The main difficulty was to find a common ground in order to describe performance for units that are rather different (comprising cities, but also isolated communes), but also to find relevant, homogenous and recent data for all studied units. In future it is important to complete the assessment by adding other environmental state/pressure indicators, but also social capital indicators (Grafton and Knowles, 2004), essential when analysing the governance component of environmental action, that could provide a more insightful image on environmental performance at local level.

\section{Database and methodology}

The present study was conducted as a three-step analysis. First it was important to define the concept of performance to be assessed.Generally, the performance is related to the fulfilment of a target, therefore the (local) environmental performance can be seen as the extent to which the communes meet the expectations of their environmental responsibility.

Gathering the data from the National Institute of Statistics (INS) as well as from the National Authority for Public Services (ANRSC), Ministry of Regional 
Development and Public Administration (MDRAP) and National Regulatory Authority for Energy Sector (ANRE) and organizing a database was the first task to accomplish for this study.It has to be mentioned that constructing a database from local level data was rather difficult, because on the one side, the data was not always available and on the other side the methods of the aggregation for the data of each county were sometimes different. Obviously, the study could be improved by adding more indicators linked for example to the recycling process, air pollution emissions, water quality management as well as biodiversity, but the access to reliable data at communal level is difficult.

Tab. 1. The indexes of local environmental performance used for the studied area

\begin{tabular}{|c|c|c|c|c|c|}
\hline Category & Index & Aggregated indicators & Period & Significance & Source \\
\hline \multirow{5}{*}{$\begin{array}{l}\text { Ecosystem } \\
\text { viability }\end{array}$} & \multirow{3}{*}{$\begin{array}{l}\text { Forestry Cover } \\
\text { Index (FCI) }\end{array}$} & The share of forest areas & $2009-2011$ & + & INS \\
\hline & & $\begin{array}{l}\text { The share of forest } \\
\text { regeneration }\end{array}$ & $2009-2011$ & + & INS \\
\hline & & $\begin{array}{c}\text { The share of forest } \\
\text { exploitation }\end{array}$ & $2009-2011$ & - & INS \\
\hline & \multirow{2}{*}{$\begin{array}{l}\text { Land } \\
\text { Degradation } \\
\text { Index }(\boldsymbol{L D I})\end{array}$} & $\begin{array}{c}\text { The share of areas provided } \\
\text { with soil protection } \\
\text { engineering }\end{array}$ & $2000-2011$ & + & INS \\
\hline & & $\begin{array}{l}\text { The share of degraded land } \\
\text { areas }\end{array}$ & 2009-2012 & - & INS \\
\hline \multirow{4}{*}{$\begin{array}{c}\text { Energy, Water } \\
\text { quality, } \\
\text { Sanitation and } \\
\text { Environmental } \\
\text { Health }\end{array}$} & $\begin{array}{l}\text { Sanitation } \\
\text { Services Index } \\
\quad \text { (SSI) }\end{array}$ & $\begin{array}{l}\text { The percent of inhabitants } \\
\text { with access to sanitation } \\
\text { services and the provenience } \\
\text { of the sanitation provider }\end{array}$ & 2014 & + & $\begin{array}{l}\text { INS, } \\
\text { ANRSC }\end{array}$ \\
\hline & \multirow{3}{*}{$\begin{array}{c}\text { Utilities } \\
\text { Modernization } \\
\text { Index (UMI) }\end{array}$} & $\begin{array}{c}\text { The percent of inhabitants } \\
\text { with access to the local } \\
\text { sewerage network }\end{array}$ & 2006-2011 & + & INS \\
\hline & & \begin{tabular}{|c|} 
The percent of inhabitants \\
with access to the local water \\
system
\end{tabular} & $2008-2011$ & + & INS \\
\hline & & $\begin{array}{c}\text { Renewable energy } \\
\text { investments (no. of projects, } \\
\text { capacities, types of RE) }\end{array}$ & $2007-2014$ & + & ANRE \\
\hline $\begin{array}{c}\text { Environmental } \\
\text { governance }\end{array}$ & $\begin{array}{l}\text { Environmental } \\
\text { Expenditures } \\
\text { Index }(\boldsymbol{E E I})\end{array}$ & $\begin{array}{c}\text { The total expenses of local } \\
\text { authorities for environmental } \\
\text { protection purposes }\end{array}$ & 2010-2012 & + & MDRAP \\
\hline
\end{tabular}

The choice of this study area was made because the environmental performance is strongly connected not only with the natural potential,but also with the social and economic components of a region, so it was considered that more interesting patterns will be revealed if the analysis is not constraint to the 
administrative boundaries of the North-East (Development) Region, but rather to the historical province of Moldavia (Western Moldavia, if one takes into account that Moldova Republic was also a part the this province), as the 8 counties of the region share both common history and strong (present) spatial interactions.

Secondly, indicators were calculated by using the available databases in order to assess the environmental performance in the studied area (table 1).

Five indexes grouped in three categories were taken into account for this study: Forestry Cover Index (FCI), Land Degradation Index (LDI), Sanitation Services Index (SSI), Environmental Expenditures Index (EEI) and Utilities Modernization Index (UMI), each constructed by the aggregation of mean values for a given (recent) period of certain indicators presenting either a positive (the share of forest areas, access to water and sewage, renewable energy investments etc.), or a negative (degraded areas) significance. LDI and the FCI are related to the way the natural capital of the units is managed, and even preserved in order to promote a sustainable development. SSI and the UMI where chosen because they give an insight on the way the local authorities assure the requirements for a good quality of life for the population by also preserving the environment. EEI reveals the importance that is given to the sustainable governance at a local level, and it allows seeing the spatial patterns of financial investments in the studied area.

As former studies acknowledged the difficulties and the inherent subjectivity of aggregating or integrating environmental performance within a single index by weighting in accordance to their relative importance (Zhou et al, 2007, Rogge, 2012), the choice for this study was not to provide a hierarchy of environmental performance at the local level, but rather to find similarities/ dissimilarities between all analysed communes in this field. The values were previously standardised and normalised but not by proximity to policy targets (as there are no such common targets yet), but to the value corresponding to the most performant unit. Finally, the analysis of bothobtained indexesand the links between themprovideda better insight on theenvironmental performance patterns allowing an equitable comparison that takes into account local peculiarities.It should be noted that FCI was calculated taking into account the location of the communes within the three major relief units (mountains, hills or plains)as an attempt to make an equitable comparison between all counties (the presence of is also a consequence of natural factors). This research aims to finding the link, if any, between the environmental performance and the administrative governance as well as finding the spatial association patterns that could lead us to a better understanding of the dynamics of certain key factors for the local environmental performance.Concerning the methods used to assess the environmental performance, the study was based on two types of analyses: 
- Aggregation of relevant indexes in different domainsof environmental performance, the evaluation of the (co)relations between them (Pearson correlation matrix) and the study of the spatial distribution of the indexes values.

- Cluster Analysis useful in order to assess similarities/dissimilarities between all local units and to identify a certain typology based on it.

The programs that facilitated this analysis where XLSTAT2014 (trial version), ArcGIS10 and Philcarto5.7.1.By using the last two, maps were made for a better visualization and in order to understand the spatial patterns of the environmental performance in Western Moldavia.

\section{Results and discussions}

As most of the East-European countries, Romania faces issues concerning the environmental protection, even though the awareness concerning the necessity of a sustainable development has constantly been raised. There are still difficulties in implementing environmental - friendly policies, the main weakness being the fact that the information and the tools concerning the environment protection are still showing a deficit, being ambiguous and not always reliable for example at a communal level.The region of Western Moldavia still faces problems concerning communist reminiscences of the restrictive policies which favoured the intensive development of the industry and did not take into account the local specificities, being difficult nowadays to sustain an environmental-friendly development as the economic possibilities are in most cases reduced.

Mapping the five indexes mentioned earlier showed different spatial patterns in what concern each field taken into account (Fig. 1). The need of the conservation of forests should be a priority for all the countries around the world, as they represent an important part in the sustainable development at any level of governance, as it assures a wide range of advantages such as economic and environmental ones. (Fig. 1)

The percent of Romania's territory covered by forests is beyond the European average (FERN, 2008), which is a reflection of an ambiguous management of the forests, given the country's natural conditions, which is mainly due to the constant changes of the legal framework as well as the unsuitable allocation of financial resources for their protection. Mapping the FCI (Fig. 1) showed that many local units from the studied area face issues related to maintaining forested areas, while the highest values are registered in Vrancea, where the lacking accessibility to forests sometimes makes the exploitation more difficult and more expensive. The other two Carpathian counties where the exploitation is higher have lower scores. This is due to the fact that the control over the illegal cuts of the trees is still poorly done and there are a lot of non-authorized transports of wood, a fact which constantly decreases the surface covered by forests and endanger the ecosystems. 
Nonetheless, one can see that there are areas with no forest cover, especially the eastern part of the region. It should also be mentioned that areas covered with trees, in the proximity of the important cities have a leisure or tourist function.

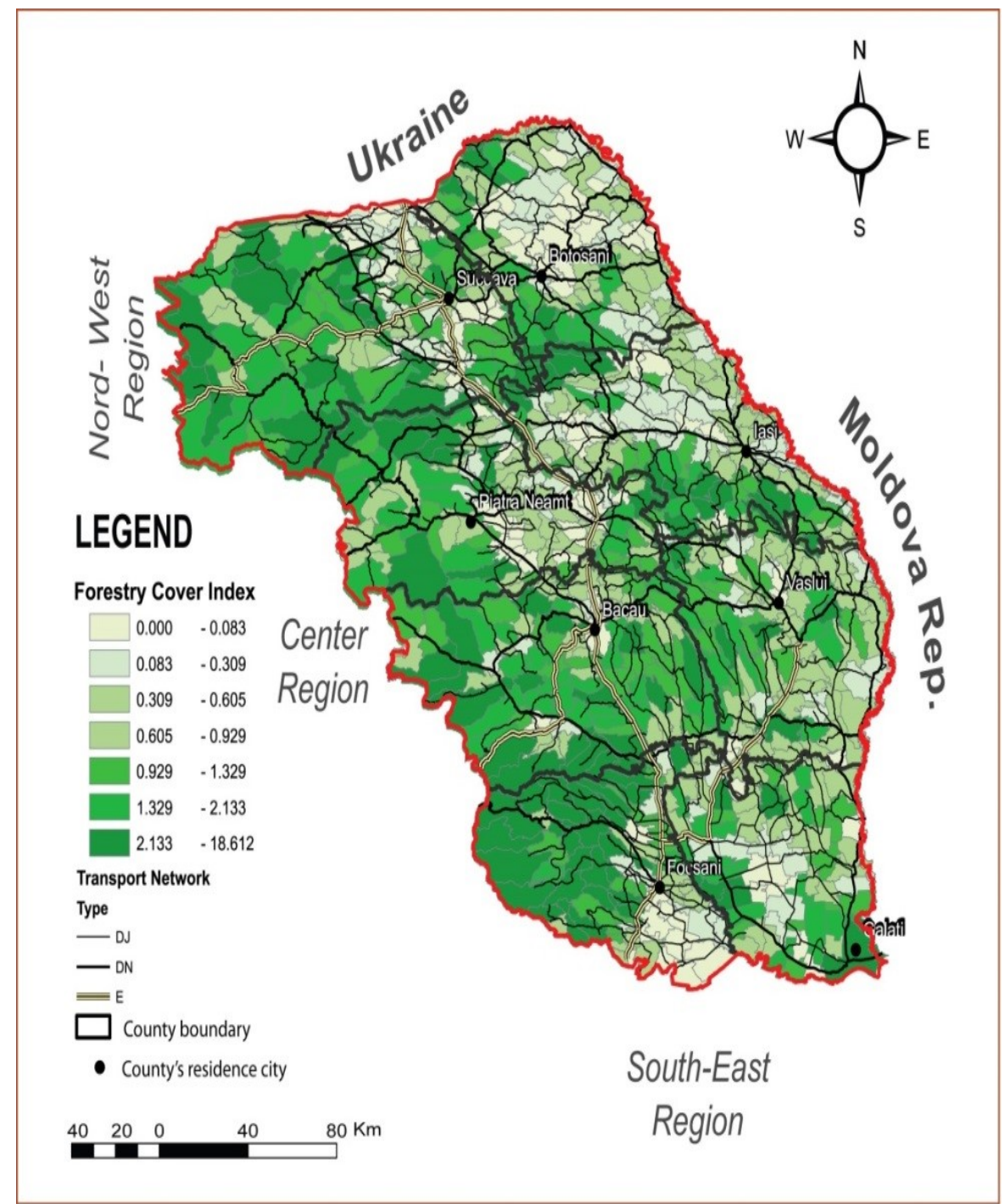

Figure 1- Forestry Cover Index (FCI) (Data source: INS)

Analysing the map showing the LDI (Fig. 2) for the Western Moldavia one could identify problems in the communes from Iasi and Vaslui County, mainly in 
Tutova Hills, which is well-known for the intense processes of erosion. In what concern the Iasi County, the intensive agriculture practiced here lead to severe land degradation, mostly due to the use of chemical substances like pesticides, chemical fertilizers etc.

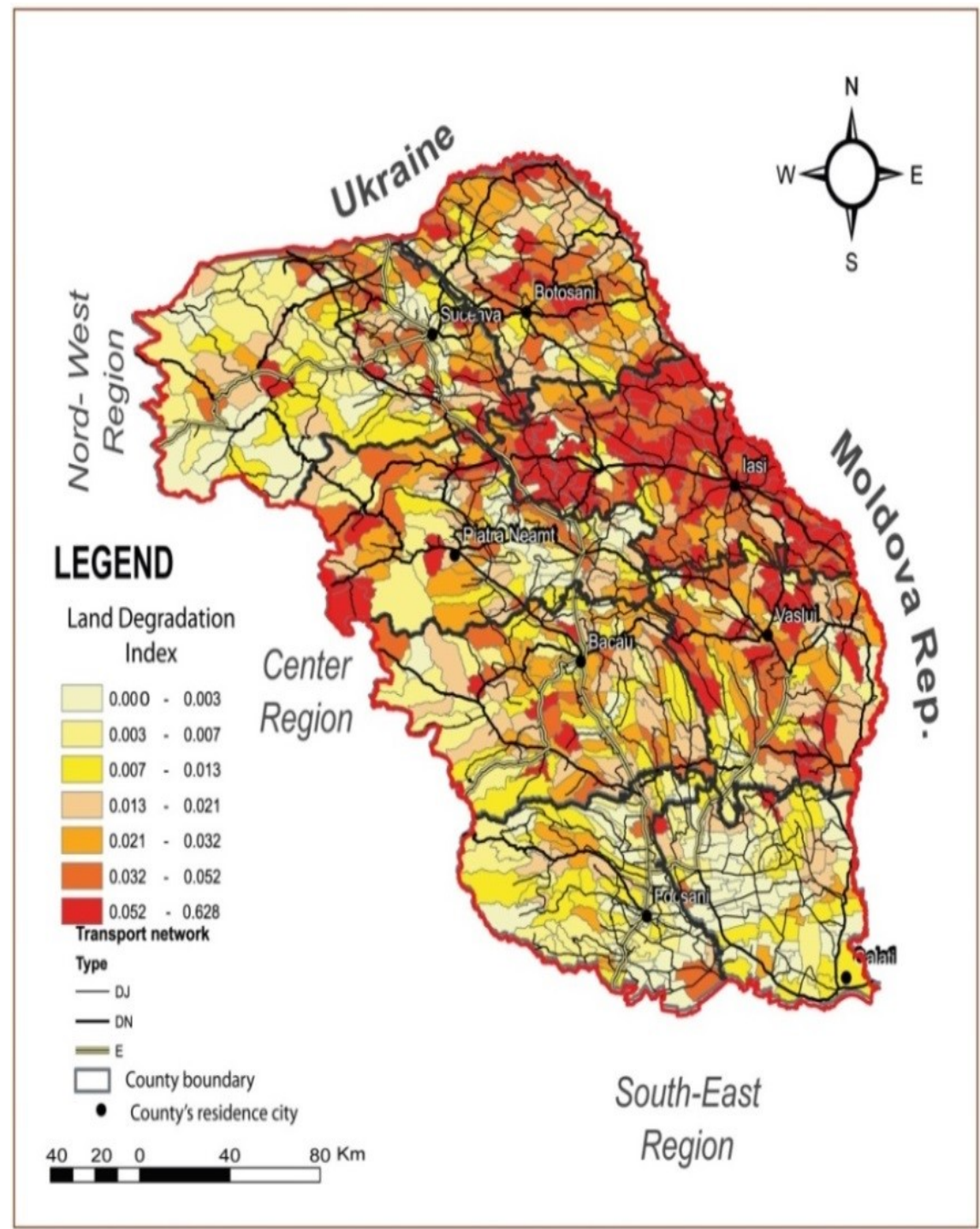

Figure 2 - Land Degradation Index (LDI) (Data source: INS) 
Meanwhile,one can observe an inverse correlation between the scores obtained by the communes for FCI and LDI, the communes with a high score for FCI obtain generally a lower score for LDI (the communes from Vrancea and Suceava counties) which emphasis the necessity of a sustainable management of the forest areasand agriculture lands (table 2).

Tab.2. Environmental performance indicators - Correlation matrix (Pearson)

\begin{tabular}{|c|r|r|r|r|r|}
\hline Variables & \multicolumn{1}{|l|}{$F C I$} & \multicolumn{1}{l|}{$S S I$} & \multicolumn{1}{l|}{ LDI } & EEI & UMI \\
\hline$F C I$ & $\mathbf{1}$ & & & & \\
\hline$S S I$ & -0.029 & $\mathbf{1}$ & & & \\
\hline$L D I$ & $\mathbf{- 0 . 1 0 8}$ & -0.036 & $\mathbf{1}$ & & \\
\hline$E E I$ & -0.035 & 0.030 & 0.056 & $\mathbf{1}$ & \\
\hline UMI & 0.000 & $\mathbf{0 . 2 2 9}$ & 0.068 & $\mathbf{0 . 0 7 6}$ & $\mathbf{1}$ \\
\hline
\end{tabular}
Values in bold are different from 0 with a significance level alpha $=0.05$

By the other hand, many units from Iasi,Vaslui or Botosani counties get high scores for the LDI and lower scores for FCI. It should, however, be noted that the processes of land degradation in Western Moldavia are not only influenced by the existence or non-existences of forests, the agricultural and construction practices playing also an important part.

SSI (Fig. 3) took into account,both the existence of a company which assures the management of the waste and, the provenience of the company. It was considered that the index relates to a good environmental performance when the sanitation company came from the same county as it limits other negatives impacts on the environment (for e.g. emissions due to transports). The database allowed the identification of 4 types of sanitation services: sanitation services assured by the commune hall, sanitation services assured by a company from the same county as the local territorial unit, sanitation services assured by a company from another county and communes without sanitation services at all.The map showing the scores for each commune indicated as expected a good coverage in the cities and in the communes around them, the proximity to an urban area being an important factor. One could observe the deficiencies in the Tazlau valley, the southern part of the county of Botosani or the mountain area of the county of Vrancea as well as in the zone of Tutovei Hills, where the poor transport infrastructure prevent the companies to assure sanitation services as the accessibility is reduced. 


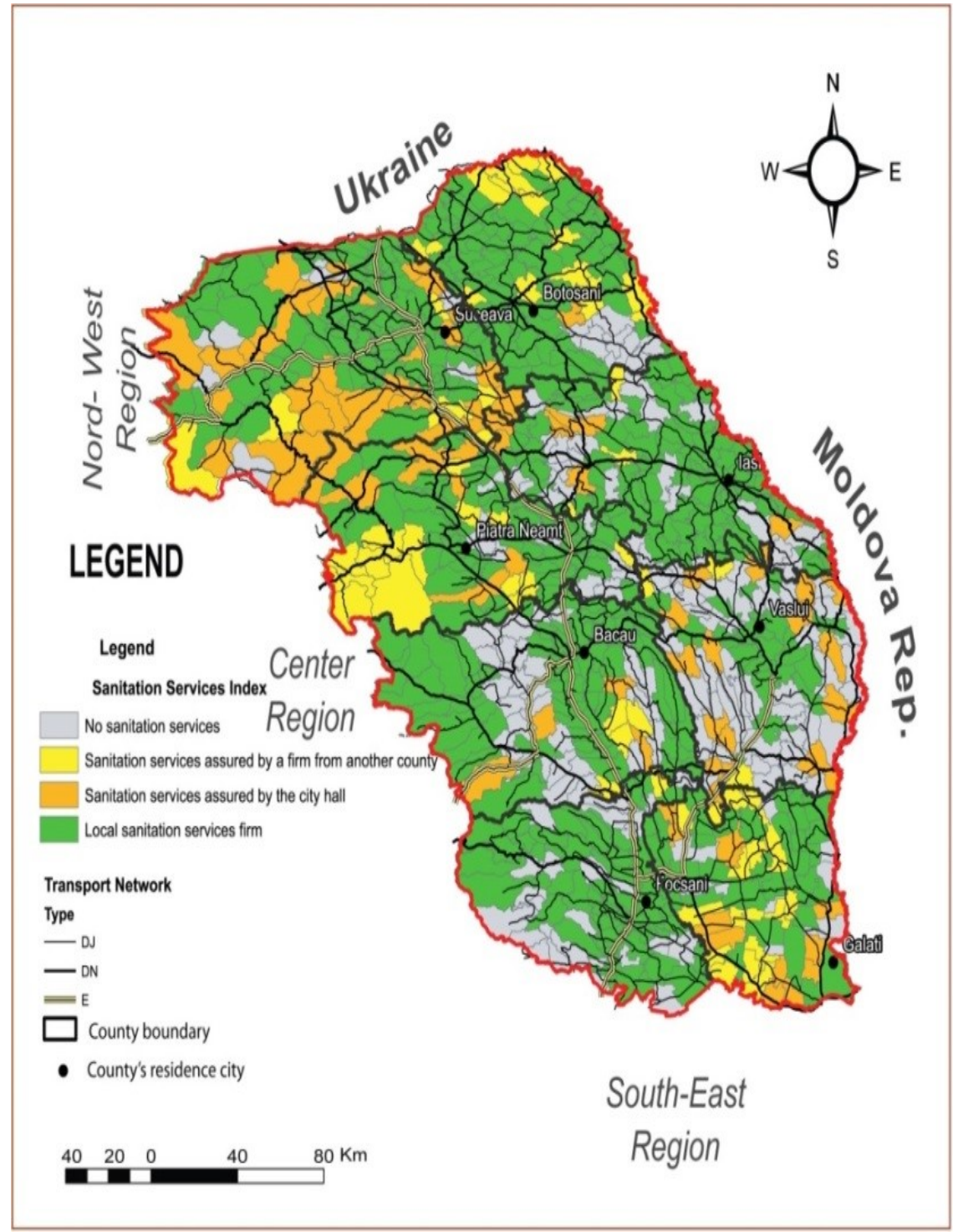

Figure 3 -Sanitation Services Index (SSI) (Data source: ANRSC)

The UMI took into account the number of persons who have access to the water system, the number of persons who have access to the sewage system, as well as the index of renewable energy which was calculated considering the 
installed power, the number of projects in the renewable energy and the number of fields of renewable energy in which investments where made (Fig. 4).

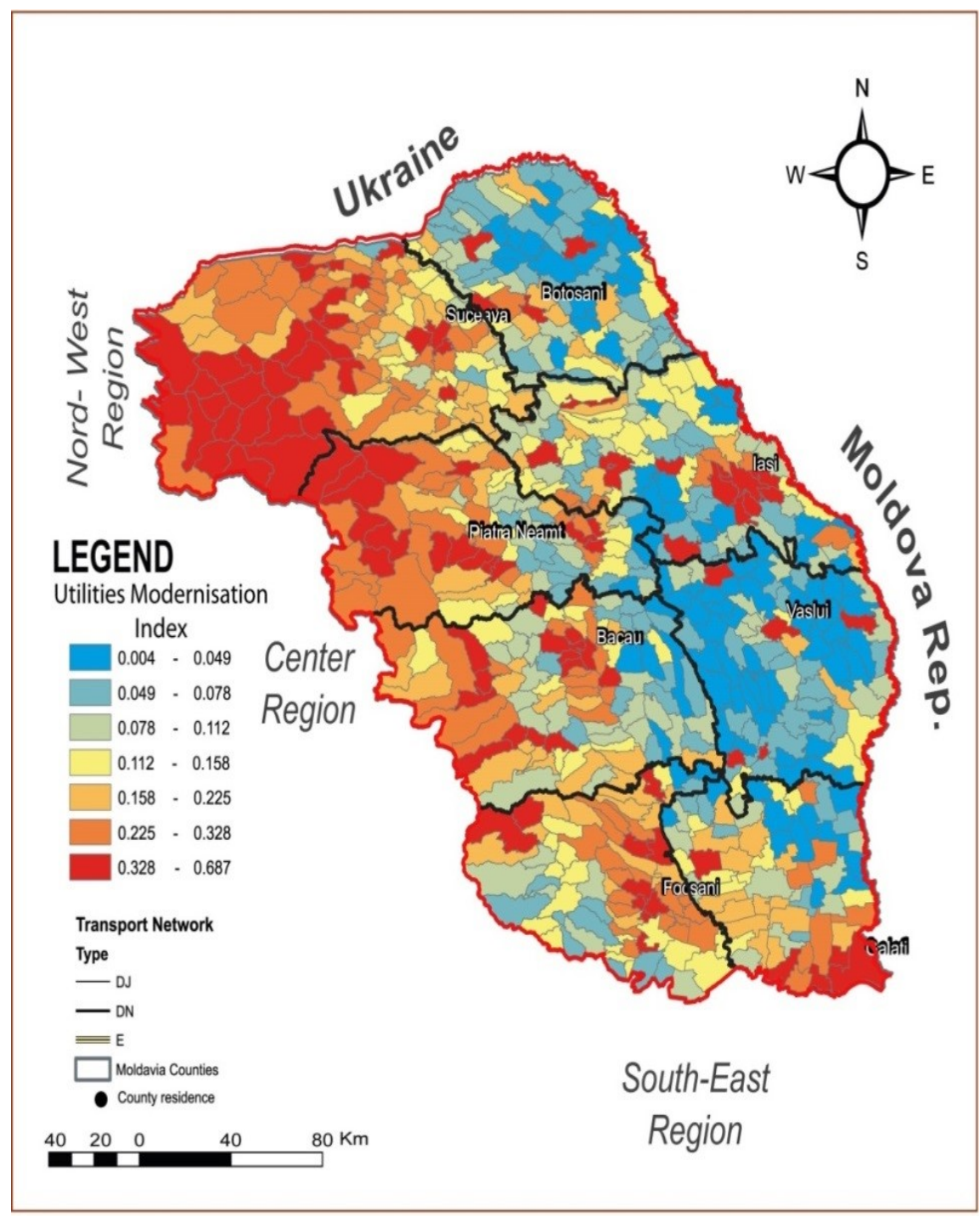

Figure 4 -Utilities Modernization Index (UMI) (Data sources: INS, ANRE)

Analysing the map one can observe an west-east opposition, the communes from the western part of the region obtaining a better score, as in the last years 
there have been significant investments concerning the access to important facilities for the population health and,meanwhile, the principal cities (for e.g. Suceava, Piatra Neamt, Focsani etc.) of these counties acted as important poles for the diffusion of modernization towards their rural hinterland. The lowest scores are observed in the counties of Vaslui and Botosani which still encounter difficulties in assuring the basic needs for all the population. The neighbourhood effect is once again observed, as the units close to a city or a town obtain better scores than the ones localized in areas remote from any urban area. However, there are cases in which even the communes close to a city (Tanacu, Solesti, Cosula etc.) do not meet the requirements for a good life quality.The above mentioned counties face the biggest problems, as it is known that poverty within these units is an important issue, and fewsustainable development solutions were found yet.

This is also demonstrated by the close relation between UMI and SSI, actually the best correlated indicators (See table 2 - Pearson coefficient in the correlation matrix - 0,229) indicating that development of rural areas should be simultaneously based on the general access to utilities, effective services and innovative green infrastructure. The communes that have both access to sanitation services but also to the main utilities and green energy are the major cities and towns, but also rural units generally located in the urban proximity (Valea Lupului and Tomesti near Iasi, Alexandru cel Bun and Savinesti close to Piatra Neamt etc.).On the contrary, small values of both indicators are related to rural peripheralization and poverty (Bogdanita, Arsura in Vaslui, Vladesti in Galati etc).

Moreover, when comparing this index with the one concerning the environmental expenditures (Fig. 5), it can be concluded that no firm actions are taken in order to improve the environmental performance of these peripheral areas. The values of EEI could prove to be one of the central factors which link the administrative efficiency with the environmental performance, as it shows the importance which is given to environment by the administrative system, and in the same time it allows seeing the degree of the efficiency of the investments. In the last years, the integration in European Union gave Romania the possibility to access important funds and grants in order to improve the sectors which faced encore deficiency in terms of socio-economic development. The EEI shows again Suceava County as being a powerful pole of diffusion for its communes, while, on the other side, in Vaslui County numerous communes have no expenditures for protecting the environment. It can be observed that there is a West - East gradient in what concerns the spatial distribution of communes which allocated or accessed important funds in order to improve the sustainable development.

The metropolitan area of Iasi stands out for the Eastern part of the analysed region, proving however that the diffusion of innovation and the territorial connexions are not as effective as in the case of Suceava or Piatra Neamt. This 
demonstrates that only if the natural potential is well managed and the general protection and services infrastructure are sustained by investments, the sustainable development could become a realistic target.

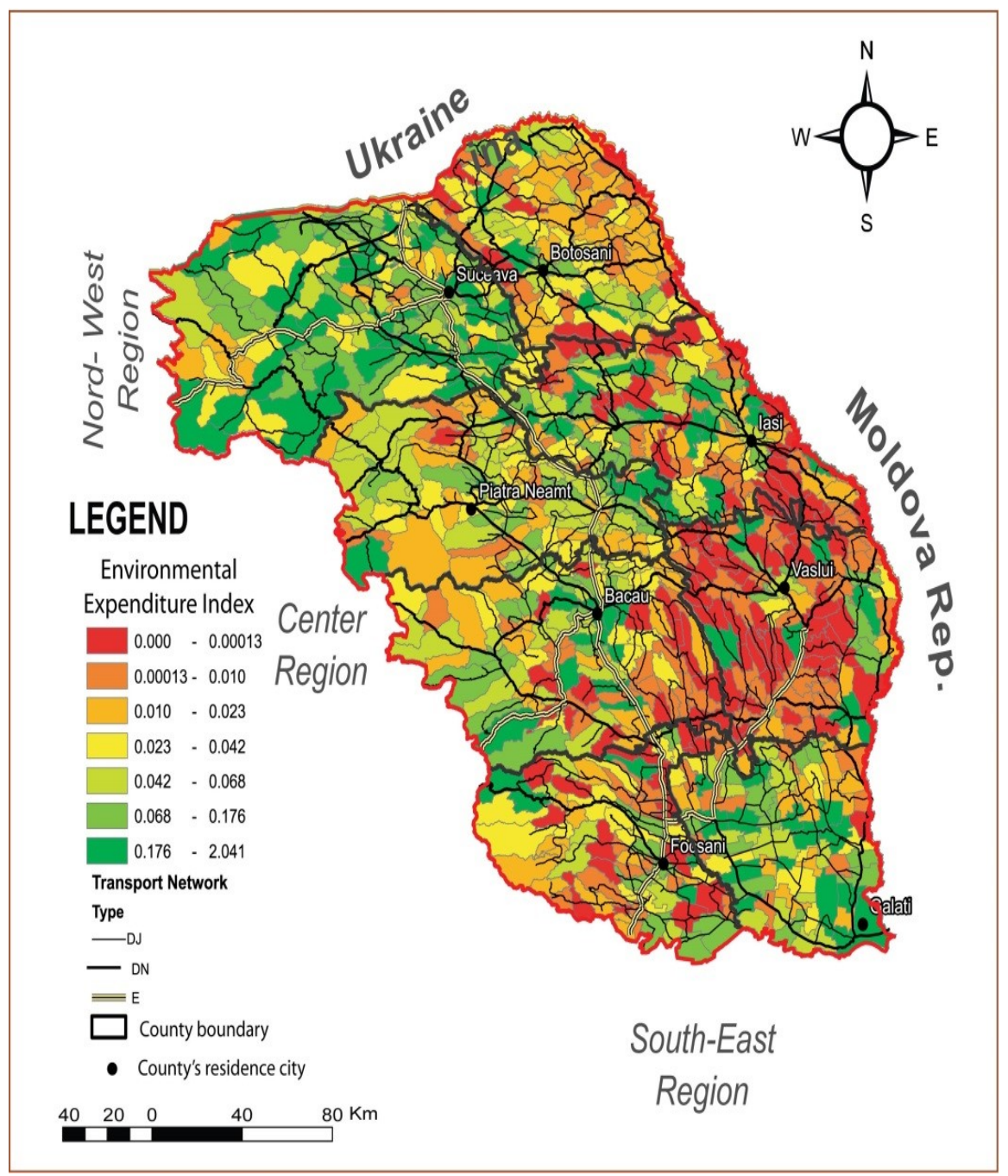

Figure 5-EnvironmentalExpenditures Index (EEI) (Data source: MDRAP)

The overall image on local environmental performance is provided by the results of a Cluster Analysis, which allowed the identification of certain categories of the communes, taking into account the fives described indexes and grouping 
their values in order to minimize the intra-class variance and maximize inter-class variance. The six profiles of the classes show the presence of major disparitiesand spatial inequitiesin life quality and environmental performance.

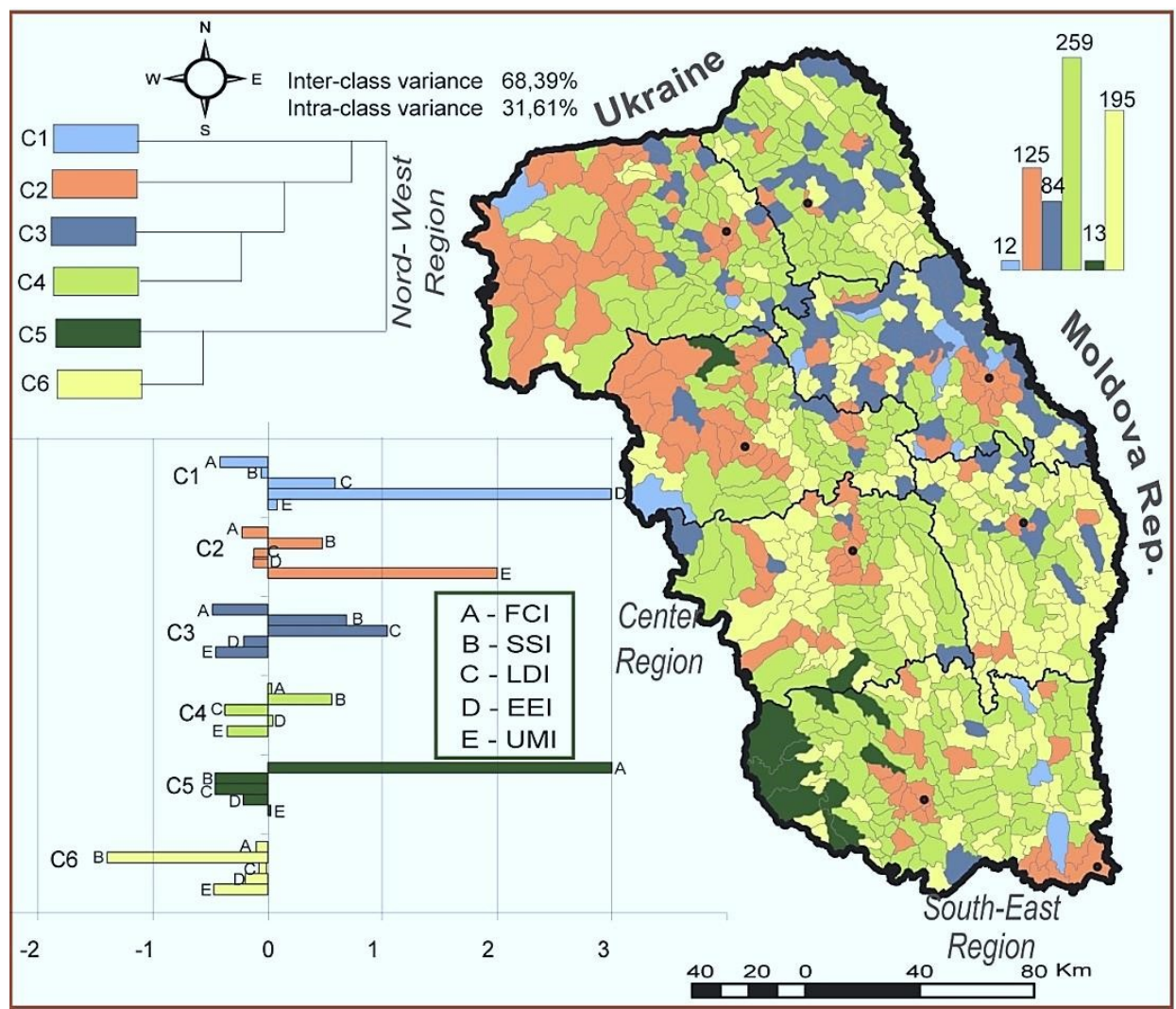

Fig. 6 The typology of relative local environmental performance in Western Moldavia

The first class (fig 6) groups rather contrastingand scattered communes (most of them in Iasi county) for whom the expenditure for the environment and utilitieswas a priority -including investments in renewable energy (Dumesti, Movileni, Motca, Aroneanu) but,they still face issues related to land degradation (Damuc, Tansa, Ipatele). It should be noted that the number of communes included in this class is rather low (13). The second class includes a much higher number the urban and rural units in which the modernization of the utilities was also a priority a fact which assured the accessibility of the population to the important services for a better life quality (when compared to the other units). It is the case of most of the cities and towns (Iasi, Suceava, Piatra Neamt, Bacau, Focsani, Botosani, 
VatraDornei etc.), peri-urban areas (Valea Lupului, Miroslava, NicolaeBalcescu, Alexandru cel Bun), and other communes especially from from Suceava and Neamt counties (Ceahlau, Pipirig)that submitted, in the last years, projects financed by European funds as an engine for development. The third class points out the communes in whom the sanitation services are well managed, as it is the case of Iasi(Popricani, Scanteia, Bivolari etc.) and, in a smaller extent, of Botosani and Suceava counties, which is in fact the only positive area of environmental performance. Meanwhile these communes confront lack of forested areas, land degradation and a rather poor environmental management and innovation. The forth class is the most wide comprising 259 units distributed in all the eight counties, in isolated but also in urban influence areas, while some are even towns, but lack real urban features (Liteni, Solca, Brosteni etc.). This heterogeneous group of communes express the average situation within the studied area. Without large forested areas (Letea Veche, Adaseni, Cudalbi etc.), but controlling the extent of degraded areas (Garoafa, MitocuDragomirnei, Trifesti etc.), the communes included in this class sometimes lack access to water and sewage networks and investments in innovating technologies (Mironeasa, Cadavinesti, Voinesti etc.).

The fifth class includes a limited number of communes (12), most of them from Vrancea County (Nereju, Campuri, Andreiasu de Jos), and only a couple units from Bacau and Neamt counties, where the lack of the accessibility or the presence of protected areas resulted in a better preservation of the forest. However this it had also resulted in negative effects for population who could not benefit from important services such as sanitation, water or waste management. The last class groups the communes with the lowest environmental performance as they have deficiency in what concerns every index took into account for the analysis, but also with low percent of land degradation areas. It's the case of the majority of the agriculture communes which are located in the rural zones of Vaslui or Bacau Counties (Tutova Hills), but also in the mountainous and Subcarpathian areas of Bacau or Neamt counties (Berzunti, Buciumi, Scorteni, Dochia, Podoleni etc.) where the population is confronted with a lack of both accessibility and local initiatives from which derives poor environmental management.

Meanwhile, one can observe a West - East segregation of the studied area, each part being confronted with specifics problems. If the communes from the East face difficulties related to land degradation and access to sanitation services, the communes from the West have issues concerning the forests management. 


\section{Conclusions}

The most important environmental pressures for Western Moldavia originate from agriculture and transports to a lesser extent from industry, as the majority of the industrial manufactures had been closed. For rural areas, the main issues are linked to the lack of accessibility to the principal utilities such as water and sewage and to sanitation services. Therefore a better management which would integrate the environmental needs for transport and utilities infrastructure as well as agriculture and sustainable energy policies is needed.The analysis pointed out that the environmental performance is lower when there is no equity and balance between the social and the economic development as they represent two essential domains of sustainable development. The spatial discrepancies also imply that regional and the local authorities should cooperate in order to assure that there is no commune excluded or disadvantaged by a certain policy or measure.It is necessary to understand the mechanisms governing the spatial planning of both urban and rural areas in order to be able to promote a development in a sustainable manner that will ensure both the economic progress and a better environmental performance.

The present study aimed at developing indicators which could give an important overview in what concerns the strengths and weaknesses of each local unit based on the extent to which they preserve their environment and it could prove to be an important tool for promoting sustainable development and resilience by directional policies which could address the actual challenges.

\section{Acknowledgment}

The work of Al. Bănică was supported by the strategic grant POSDRU/159/1.5/S/133652, co-financed by the European Social Fund within the Sectorial Operational Program Human Resources Development 2007 - 2013

\section{References}

Bănică Al., Sandu Alexandra, Breabăn Iuliana Gabriela, (2013), Resilient Romanian Regions: Recent trends in environmental performance, presentation at IX-th International Conference Man-City-Nature, Integrated development of cities and regions, 14-15 octombrie 2013, Torun, Polonia.

Bălteanu D., Popovici Elena Ana,(2010), Land use changes and land degradation in postsocialist Romania, Romanian Journal of Geography, vol. 54 (2).

Bellenger M. J., Herlihy A. T., (2010), Performance-based environmental index weights. Are all metrics created equal?, Ecological Economics 69 (2010) 1043-1050.

Bran Florina, Rădulescu Carmen Valentina, Ioan Ildiko, (2011), Measures of Environmental Performance, Review of International Comparative Management, Volume 12, Issue 5, December 2011. 
Breabăn Iuliana Gabriela, Bănică Al., Sandu Alexandra, (2013), Using Environmental Performance Index to Assess Regional Resilience in Romania, Conference Proceedings, International Science Conference, Reporting for Sustainability, Environmental Management Center Serbia, p. 275 - 281.

Burja V, Burja Camelia, (2009), Increasing services quality through environmental performance management, Annales Universitatis Apulensis, Series Oeconomica, 11(2), 2009.

Esty D. C., Levy M. A., Srebotnjak T., Sherbinin A. de,(2005), 2005 Environmental Sustainability Index: Benchmarking National Environmental Stewardship. New Haven: Yale Center for Environmental Law and Policy.

Esty D. C., Levy M. A., Srebotnjak T., Sherbinin A. de, Kim C., Anderson B., (2006), Pilot 2006 Environmental Performance Index. New Haven: Yale Center for Environmental Law and Policy.

Esty D. C., Levy M. A., Kim C. H., Sherbinin A. de, Srebotnjak T., Mara V., (2008), 2008 Environmental Policy Index. New Haven: Yale Center for Environmental Law and Policy.

Grafton R. Q., Knowles S. (2004), Social Capital and National Environmental Performance: A Cross-Sectional Analysis, The Journal of Environment \& Development December 2004 13: 336-370.

Mini J. S, (1992), Développement durable des forêts, Revue internationale des forêts et des industries forestières - Vol. 43, FAO.

Mocanu-Perdichi Ruxandra (2009), Indexul dezvoltării durabile în România la nivel judeţean şi regional, Revista Inovaţia Socială nr. 1/2009 (ianuarie-iunie) pp. 1-19, Institutul de Cercetare a Calității Vieții, București.

Nogueiro L., Ramos T. B.,(2014), The integration of environmental practices and tools in the Portuguese local public administration, Journal of Cleaner Production, Volume 76, 1 August 2014, Pages 20-31, ISSN 0959-6526.

Perotto Eleonora, Canziani R, Marchesi R, Butelli, Paola, (2008), Environmental performance, indicators and measurement uncertainty in EMS context: a case study, Journal of Cleaner Production 16 (2008) 517-530.

Rogge N., 2012. Undesirable specialization in the construction of composite policy indicators: The Environmental Performance Index, Ecological Indicators 23 (2012) 143-154.

Sova R., Rault C., Caporale Guglielmo Maria, Sova Anamaria, (2014), Improving Environmental Performance: A Challenge for Romania, Environmental and Resource Economics, Volume 57, Issue 3, pp 431-452, Springer.

Sun J. H., Hu J., Yan J. M., Liu Z., Shi Y. R., (2012), Regional Environmental Performance Evaluation: A Case of Western Regions in China, Energy Procedia, Volume 16, Part A, 2012, Pages 377-382, ISSN 1876-6102.

Surd V., Alexe Rădița, Kantor Camelia-Maria, Tanislav D., Sencovici Mihaela, (2011),The Evaluation of the Environmental Quality in Romania, Geographica Pannonica 15, 2, ISSN 0354-8724 (hard copy), ISSN 1820-7138 (online). 
Tabără N., Nuță F. M, Nuță Alina Cristina, (2013), A review of the actual state of environmental performance of Romania-EPI 2012, Journal of Public Administration, Finance and Law, Issue 4.

Veyret Yvette. (dir), (2007), Le développement durable, Edition Sedes, Paris, 432 pages.

ZhouP., Poh K. L., Ang B. W., (2007),A non-radial DEA approach to measuring environmental performance, European Journal of Operational Research 178 (2007) 19.

*** (2001), Environmental Performance Review of Romania: Second Review, United Nations Report, New York and Geneva.

*** (2003), Draft report on the environment, EPA, Publication no.EPA 260-R-02-006.

*** (2008), Funding forests into the future? How the European Fund for Rural Development affects Europe's forests, FERN, June.

*** (2010), Towards a China Environmental Performance Index - EPI China, Final Report, New Haven: Yale Center for Environmental Law and Policy, p 14.

*** (2012), Environmental Performance Review of Romania: Second Review, United Nations Report, New York and Geneva. 